\title{
The effect of desiccation on water sorption,solubility and hygroscopic volumetric expansion of dentine replacement materials
}

DOI:

10.1016/j.dental.2018.05.012

\section{Document Version}

Accepted author manuscript

Link to publication record in Manchester Research Explorer

Citation for published version (APA):

Mustafa, R., Alshali, R., \& Silikas, N. (2018). The effect of desiccation on water sorption,solubility and hygroscopic volumetric expansion of dentine replacement materials. Dental Materials.

https://doi.org/10.1016/j.dental.2018.05.012

\section{Published in:}

Dental Materials

\section{Citing this paper}

Please note that where the full-text provided on Manchester Research Explorer is the Author Accepted Manuscript or Proof version this may differ from the final Published version. If citing, it is advised that you check and use the publisher's definitive version.

\section{General rights}

Copyright and moral rights for the publications made accessible in the Research Explorer are retained by the authors and/or other copyright owners and it is a condition of accessing publications that users recognise and abide by the legal requirements associated with these rights.

\section{Takedown policy}

If you believe that this document breaches copyright please refer to the University of Manchester's Takedown Procedures [http://man.ac.uk/04Y6Bo] or contact uml.scholarlycommunications@manchester.ac.uk providing relevant details, so we can investigate your claim.

\section{OPEN ACCESS}


Title:

The effect of desiccation on water sorption, solubility and hygroscopic volumetric expansion of dentine replacement materials

\section{Authors:}

Ruba Mustafa, ${ }^{\text {b, }}$, Ruwaida Z. Alshali ${ }^{c}$, Nick Silikas ${ }^{a}$

${ }^{a}$ School of Dentistry, The University of Manchester, Manchester, UK.

${ }^{\mathrm{b}}$ Conservative and Department, Faculty of Dentistry, Jordan University of Science and Technology, Irbid ,Jordan.

${ }^{c}$ Oral and Maxillofacial Prosthodontics Department, Faculty of dentistry, King Abdulaziz University, Jeddah, Saudi Arabia

\section{Short title:}

Effect of desiccation on dentine replacement materials

\section{Corresponding author:}

Dr Nick Silikas

School of Medical Sciences, The University of Manchester, Manchester, UK M13 9PL

Phone: +441612756747

E-mail: nick.silikas@manchester.ac.uk

\section{Keywords:}

Sorption, solubility, hygroscopic expansion, desiccation, dentine replacement 


\section{Objectives}

To evaluate water sorption, solubility and hygroscopic expansion and the effect of desiccation for a calcium silicate-based material, a conventional glass ionomer, and a resinmodified glass ionomer.

\section{Material and methods}

Water sorption, solubility and hygroscopic expansion of Biodentine ${ }^{T M}$ (BD), GC Fuji IX GP ${ }^{\circledR}$ FAST (FJ), and Ionolux (IO) were tested under two pre-storage conditions: with desiccation and without desiccation. Disc-shaped samples $(n=5)$ were immersed in water and weighed at different time intervals ( $1 \mathrm{~h}, 24 \mathrm{~h}, 3 \mathrm{~d}, 7 \mathrm{~d}$ and $30 \mathrm{~d}$ ) and hygroscopic expansion was recorded at $7 \mathrm{~d}$ and $30 \mathrm{~d}$. Data were analysed using Factorial repeated measures ANOVA, one-way/ two- way ANOVA, Independent samples T-test and Tukey's post hoc test ( $\alpha=$ $0.05)$.

\section{Results}

With desiccation, sorption of $\mathrm{IO}$ and FJ was $124.33 \mu \mathrm{g} / \mathrm{mm}^{3}$ and $79.97 \mu \mathrm{g} / \mathrm{mm}^{3}$ respectively. Solubility was $-12.36 \mu \mathrm{g} / \mathrm{mm}^{3}$ for 10 and $-20.19 \mu \mathrm{g} / \mathrm{mm}^{3}$ for FJ. Hygroscopic expansion was $3.01 \%$ for $1 \mathrm{O}$ and $-2.35 \%$ for FJ.

Without desiccation, sorption was in the order: IO> BD $>$ FJ $\left(130.35 \mu \mathrm{g} / \mathrm{mm}^{3}\right.$, $122.07 \mu \mathrm{g} / \mathrm{mm}^{3}$, and $107.21 \mu \mathrm{g} / \mathrm{mm}^{3}$ respectively), while solubility order was: $\mathrm{BD}>\mathrm{FJ}>\mathrm{IO}$ $\left(154.83 \mu \mathrm{g} / \mathrm{mm}^{3}, 88.82 \mu \mathrm{g} / \mathrm{mm}^{3}\right.$, and $25.67 \mu \mathrm{g} / \mathrm{mm}^{3}$ respectively). IO and FJ showed significant difference in sorption and solubility between the two pre-storage treatment groups $(p<0.005)$. Hygroscopic expansion was in the order: IO> BD > FJ.

\section{Conclusions}

BD had the highest solubility while IO had the least. The relatively stable polymeric resin in IO may contribute to its low solubility but high hygroscopic expansion. Desiccation had significant effect on sorption, solubility and volumetric expansion of water-based materials.

\section{Key words}

Sorption, solubility, hygroscopic expansion, desiccation, dentine replacement. 


\section{Introduction}

Replacing lost dentine has been a major problem in clinical dentistry for several years [1]. By the end of the 1960s, Wilson and Kent introduced glass ionomer cement (GIC) which is also called glass polyalkenoate cements [2, 3]. GIC have good ion migration and particle adaptation which result in an interactive zone formation and chemical bond between GIC and the tooth surface [4]. Lamination or sandwich technique using conventional glass ionomer has been introduced as a dentin replacement method [5].

With further GIC development, the resin modified GIC (RMGIC) has been marketed by the late 1980s and it has been used in the sandwich technique as a dentine replacement material [6]. Adding the hydrophilic hydroxyethyl methacrylate monomers (HEMA) to GIC results in improved chemical and mechanical properties [7, 8]. A number of other materials have been suggested to be used as dentine relplacement materials including bioglasses [9] and the new generation flowable bulk-fill resin-composites such as Smart Dentine Replacement (SDR) [10].

Part of this evolution process is Biodentine $\mathrm{TM}^{\mathrm{TM}}(\mathrm{BD})$, which is new water calcium-based cement, that has been developed in 2010 and offers a bioactive, biocompatible and biointeractive dentine replacement material [11]. The powder contains tricalcium and dicalcium silicate $\left(3 \mathrm{CaO} . \mathrm{SiO}_{2}\right.$ and $\left.2 \mathrm{CaO} . \mathrm{SiO}_{2}\right)$ as a core material. Calcium carbonate $\left(\mathrm{CaCO}_{3}\right)$ makes up approximately $15 \%$ of the material (according to the manufacturer) $[12,13]$ and it performs as a nucleation site and a filler [14]. Zirconium dioxide $\left(\mathrm{ZrO}_{2}\right)$, which makes approximately $5 \%$ of Biodentine, acts as a radiopacifier material [15-18].

Although the practice of dentin replacement using the 'liner' or 'base' approach may have negative tendency to affect the restoration longevity as has been shown by a recent systematic review [19], it may be legitimate to apply BD as a dentin replacement material compared to other materials mainly due to its effect on preserving the pulp vitality through its bioactive therapeutic effect. Furthermore, it has an antibacterial effect that makes it suitable for deep caries cavities [20] as well as an excellent bond and seal with dentine, short setting time, and good mechanical properties [21]. On the other hand, it does not have a satisfactory wear resistance, mechanical strength and aesthetic to be a definitive restoration. Therefore, BD should be covered by a resin-composite layer similar to GIC (sandwich technique) [1]. Since BD is relatively weak during its initial setting period, coverage by a resin- 
composite should be delayed for at least fourteen days since its first application as recommended by the recent study. This should provide adequate time for BD to mature and withstand the polymerisation contraction force of the resin-composite [22]. Thus, during the first two weeks of its application, BD is left directly exposed to oral fluids which might negatively affect the material through water sorption and solubility, especially that water sorption has been shown to be the fastest during the first 2-3 weeks before reaching the saturation phase [23].

The lifespan of a restorative material in the aggressive environment of the oral cavity is dependent on a number of clinical factors and material's properties including its resistance to water absorption, solubility, and volumetric expansion. The hydrolytic stability of a restorative material affects its durability and the treatment success [24]. In addition, solubility and water sorption may contribute to microleakage [25] which could indirectly result in restoration failure [26]. Accordingly, it is desirable to have water sorption and solubility as low as possible [24].

Currently, there is no a specific standard for testing water sorption, solubility, and volumetric expansion of water-based materials. A number of studies aimed to mimic the in vivo situation by immersing the samples directly in water without desiccation [27]. However, in other studies the ISO 4049 (2009) standard for assessing polymeric materials have has been followed to assess materials such as GIC $[28,29]$ which involves desiccating the test materials in order to reach an initial stable mass after removing the free water molecules from the materials. 3D hygroscopic expansion is one of the recognised techniques for dimensional changes of materials in water [30]. In the current study, both techniques were used to assess the effect of desiccation on different properties of water-based materials. The aims of this study were to assess water sorption, solubility and volumetric expansion of water-based dentine replacement materials and the effect of pre-immersion desiccation on these measurements. The null hypotheses tested were: i) there is no difference in water sorption, solubility and 3-D hygroscopic expansion of different materials, and ii) there is no effect of pre-storage desiccation on water sorption, solubility and volumetric expansion, of tested materials. 


\section{Materials and Methods}

The materials investigated in this study (Table 1) were Biodentine ${ }^{T M}(B D)$, GC Fuji IX GP FAST (FJ), and Ionolux (IO) which respectively represent a calcium silicate-based material, a conventional glass ionomer, and a resin modified glass ionomer.

Disc-shaped samples of each material were prepared using PTFE moulds of $15.0 \mathrm{~mm}$ $( \pm 0.1 \mathrm{~mm})$ internal diameter and $2 \mathrm{~mm}( \pm 0.1 \mathrm{~mm})$ thickness. The mould was set on a glass microscopic slide with a transparent film. The mould was slightly overfilled with the material and another film and glass slide were applied on the top with pressure. Clamps were used to maintain the pressure during materials setting.

According to ISO 6876, BD was placed in the moulds and allowed to set at $37^{\circ} \mathrm{C}$ and $99 \%$ relative humidity for $9 \mathrm{~min}$ (70\% of the final setting time). FJ moulds were also set for 15 minutes at $37 \pm 1^{\circ} \mathrm{C}$ and a relative humidity value of $95 \pm 5 \%$. 10 specimens were irradiated at five overlapping points on each side for 20 s using an Optilux light curing unit (Optilux 501, USA) with an irradiance of $620 \mathrm{~mW} / \mathrm{cm}^{2}$. The tip of the light curing unit was approximately $1 \mathrm{~mm}$ away from the specimen surface. Each sample was checked for voids and irregularity and any excess flash was removed using 1000 grit silicon carbide abrasive paper. A digital electronic calliper (Mitutoyo Corporation, Japan) was used to measure the specimen thickness and diameter at 4 and 3 points respectively. The mean values were used to calculate the specimen volume (v). Each sample was then placed in a labelled glass bottle.

\section{Pre-storage treatment and immersion in water}

Ten samples of each material were prepared and then divided into two groups of five samples each. For the first group, the samples were subjected to a pre-storage dry treatment (desiccation) after complete setting and before they were immersed in water following the ISO standard number 4049 (2009). In the second group, the specimens were directly immersed in water after complete setting according to ISO 6876 (2012).

In the first group, desiccation was carried out by transferring the specimens into a desiccator with anhydrous silica gel at $(37 \pm 1)^{\circ} \mathrm{C}$ for $22 \mathrm{~h}$. After that, the specimens were stored in another desiccator at $(23 \pm 1){ }^{\circ} \mathrm{C}$ for $2 \mathrm{~h}$. A calibrated electronic balance with $0.01 \mathrm{mg}$ accuracy (Ohaus Analytical Plus, Ohaus Corporation, USA) was used to weigh the 
specimens. This desiccation cycle was repeated until a sample mass was obtained with no more than $\pm 0.1 \mathrm{mg}$ mass change in any $24 \mathrm{~h}$ period. This mass was denoted as $\mathrm{m} 1$.

The samples were then immersed in $10 \mathrm{ml}$ of distilled water and stored at $37{ }^{\circ} \mathrm{C}$ and weighed periodically. Before weighing, each specimen was rinsed with water and gently dried with filter paper and waved for $15 \mathrm{~s}$. After one minute, the mass for each sample was obtained and the specimen was then immersed again in distilled water. This procedure was carried out to obtain the mass $m(t)$ for each specimen after 1 h, 24 h, 3 days, 7 days, and 28 days. The final saturated mass after 28 days was denoted as $\mathrm{m} 2$. Finally, the specimens were dried in a desiccator until a constant mass (m3) was recorded to the nearest $0.001 \mathrm{~g}$. Measurements were repeated three times and the mean value was calculated.

For the second group, the specimens were weighed to obtain $\mathrm{m} 1$ and immersed directly in $10 \mathrm{ml}$ of distilled water at $37^{\circ} \mathrm{C}$ without desiccation. The same periodical measurement procedure was carried out to obtain $\mathrm{m} 2$ as was described earlier for the first group.

\section{Hygroscopic expansion measurement}

A custom-built non-contact laser micrometer (Measuring Unit LSM-503s and Display Unit LSM-6200, Mitutoyo Corporation, Japan) was used to record the diametral changes of the specimens to $200 \mathrm{~nm}$ resolution. This device consisted of a laser-scan micrometer mounted on a stainless steel base, a disc specimen holder that rotates in a horizontal plane, a stepper-control unit, which maintains stepwise rotation of the disc sample, and a display unit. This laser micrometer was connected to a computer for further data processing and recording. The device principle was described previously [31].

The initial mean diameter $d_{1}$ of each specimen was measured before desiccation and water immersion for the first and second groups respectively. After one week of water immersion for both groups, each specimen was dried carefully with filter paper till no visible water appeared on the disk. Disc was put on the specimen holder and 500 readings were recorded for each disc and the average value was calculated. After recording the measurement, the sample was returned directly to water. The same procedure was repeated again after one month. 


\section{Calculation of sorption, solubility, and volumetric expansion}

The following equations were used for calculation of percentage mass change (PMC), sorption, and solubility of different materials [32]:

PMC (\%) $=\frac{m(t)-m 1}{m 1} \times 100$

Sorption $\left(\mu \mathrm{g} / \mathrm{mm}^{3}\right)=\frac{m 2-m 3}{v}$

Solubility $\left(\mu \mathrm{g} / \mathrm{mm}^{3}\right)=\frac{m 1-m 3}{v}$

Sorption (\%) $=\frac{m 2-m 3}{m 1} \times 100$

Solubility $\mathbf{( \% )}=\frac{m 1-m 3}{m 1} \times 100$

Where $\mathrm{m} 1$ is the material's mass before water immersion, $\mathrm{m}(t)$ is the material's mass at different immersion periods, $\mathrm{m} 2$ is the material's mass when it is fully saturated, $\mathrm{m} 3$ is the material's mass after final desiccation (desorption), and $v$ is the specimen's volume in $\mathrm{mm}^{3}$.

For calculation of the percentage hygroscopic volumetric expansion $\mathrm{V}(\%)$, the percentage diametric change $\Delta \mathrm{d}(\%)$ was first calculated according to the following equation:

$\Delta \mathrm{D}(\%)=\frac{d 1-d(t)}{d 1} \times 100$

Where $\mathrm{d} 1$ is the specimen's diameter before water immersion, and $d(t)$ is the specimen's diameter at different immersion periods. $V(\%)$ was then calculated using the following equation(29):

$\mathbf{V}(\%)=\left[\left(1+\frac{\Delta d(\%)}{100}\right)^{3}-1\right] \times 100(7)$

\section{Statistical Analysis}

Data were entered into a statistical software package (SPSS, V20, Chicago, USA). Data were checked for normality by assessing the modality and the degree of skewness and Kurtosis, 
and were considered normally distributed. Factorial repeated measures ANOVA with Bonferroni adjustment for multiple pair-wise comparisons was used to assess the change in percentage mass change over storage time and its interaction with the material type and the type of pre-storage treatment (with desiccation or without desiccation). Two-way ANOVA was used to assess the interaction between the material type and the type of treatment on sorption, solubility, and volumetric expansion. One-way ANOVA was used to assess differences in sorption, solubility, and volumetric expansion between materials at each storage condition. Tukey HDS and Dunnett T3 post hoc tests were used for multiple comparisons according to the homogeneity of variances of data. Independent samples Ttest was used to assess differences in sorption, solubility, and volumetric expansion of each material when two different types of pre-storage treatment were applied. Paired samples Ttest, was used to assess differences in volumetric expansion at $1 \mathrm{w}$ and $1 \mathrm{~m}$ for each material, at both storage conditions. All the tests were conducted at a significance level of $\alpha=0.05$. 


\section{Results}

Sorption, solubility, and percentage mass change data of the different materials with desiccation and without desiccation pre-storage treatment are summarized in Tables 2 and 3. Data were expressed as mean values and standard deviation. Results regarding BD with desiccation pre-storage treatment were not applicable since all samples have become severely cracked and broken once they were immersed in water.

Factorial repeated measures ANOVA and two-way ANOVA tests showed a significant interaction between immersion time and the type of material $(p<0.005)$, immersion time and the type of pre-storage treatment $(p<0.05)$, and between the material type and the prestorage treatment type $(p<0.005)$ on sorption and solubility.

Both $\mathrm{IO}$ and FJ (with desiccation or without desiccation) showed positive percentage mass change values at all immersion times while $\mathrm{BO}$ showed negative values.

Both $\mathrm{IO}$ and $\mathrm{FJ}$ (whether with desiccation or without desiccation) showed significant difference in percentage mass change as a function of time $(p<0.005)$ except between $1 \mathrm{w}$ and $1 \mathrm{~m}$ in 10 where the difference was not significant $(p=0.12)$. Desiccation treatment demonstrated significantly greater percentage mass change values at each immersion time than no desiccation treatment except for 10 at $1 \mathrm{~h}$ and $1 \mathrm{~d}$ immersion times where the difference was not significant. Generally, the difference in percentage mass change between dry and wet treatments becomes greater with time with FJ showing greater difference than IO at all immersion times. BD with wet treatment showed negative percentage mass change values which significantly increase in negative value as a function of time $(p<0.05)$ except at the period between $1 d$ and $3 d(p=1.00)$ and the period between $3 d$ ad $1 w(p=0.28)$ where the material appeared stable (Figure 1).

With desiccation treatment IO showed significantly lower percentage mass change until $1 \mathrm{~d}$ compared to FJ $(p<0.005)$, however, between $1 \mathrm{~d}$ and $1 \mathrm{~m}$ FJ demonstrated significantly lower percentage mass change compared to $10(p<0.005)$. Without desiccation, one-way ANOVA and post hoc testing (Dunnett T3) showed significant difference in percentage mass change at all immersion times between all materials $(p<0.005)$. Percentage mass change was in the order: $10>\mathrm{FJ}>\mathrm{BD}$. 
With regards to sorption and solubility values (Table 2,3 ) expressed in $\mu \mathrm{g} / \mathrm{mm}^{3}$ and in \%, 10 showed significantly higher sorption $\left(124.33 \mu \mathrm{g} / \mathrm{mm}^{3}, 6.43 \%\right)$ and solubility values $(-12.36$ $\left.\mu \mathrm{g} / \mathrm{mm}^{3},-0.64 \%\right)$ compared to FJ sorption $\left(79.97 \mu \mathrm{g} / \mathrm{mm}^{3}, 3.84 \%\right)$ and solubility $(-20.19$ $\left.\mu \mathrm{g} / \mathrm{mm}^{3},-0.97 \%\right)$ when samples received desiccation pre-storage treatment $(p<0.005)$. When the materials were not desiccated, one-way ANOVA followed by Tukey HSD post hoc test showed significant differences between IO, FJ, and BO $(p<0.005)$. Sorption values were in the order: $\mathrm{IO}>\mathrm{BO}>\mathrm{FJ}\left(130.35 \mu \mathrm{g} / \mathrm{mm}^{3}, 122.07 \mu \mathrm{g} / \mathrm{mm}^{3}\right.$, and $107.21 \mu \mathrm{g} / \mathrm{mm}^{3}$ respectively), while solubility values were in the order: BO> FJ> IO $\left(154.83 \mu \mathrm{g} / \mathrm{mm}^{3}, 88.82\right.$ $\mu \mathrm{g} / \mathrm{mm}^{3}$, and $25.67 \mu \mathrm{g} / \mathrm{mm}^{3}$ respectively). Percentage sorption and solubility values followed the same order.

Independent samples T-test applied for 10 showed significant differences in sorption and solubility between the two pre-storage treatments $(p<0.05)$. Higher sorption and solubility values were demonstrated when no desiccation treatment was carried out compared to the desiccated group. Similarly, but with higher extent, FJ showed significantly higher sorption and solubility values when samples were not desiccated compared to the desiccated group $(p<0.005)$ (Figure 2).

Data for volumetric expansion are summarized in Table 4. All materials showed positive volumetric expansion at $1 \mathrm{w}$ and $1 \mathrm{~m}$ except FJ which demonstrated negative volumetric expansion (i.e. shrinkage) when subjected to desiccation pre-treatment. Two-way ANOVA showed no significant interaction between the type of material and the type of pre-storage treatment on volumetric expansion at $1 \mathrm{w}(p=0.39)$ or $1 \mathrm{~m}(p=0.90)$.

IO showed significantly higher volumetric expansion at $1 \mathrm{~m} ; 3.01 \%$ (with desiccation) and 6.19\% (without desiccation) compared to FJ and BD $(p<0.005)$ (Table 4). Volumetric expansion of non-desiccated FJ and BD at $1 \mathrm{~m}$ was not significantly different $(p=0.91)$ with values of $1.02 \%$ and $1.51 \%$ for $\mathrm{FJ}$ and $\mathrm{BO}$ respectively. For both $\mathrm{FJ}$ and $\mathrm{IO}$, volumetric expansion was significantly higher when the materials were not desiccated compared to desiccated materials. However, FJ was more influenced by the type of pre-storage treatment $(p<0.005)$ compared to $10(p=0.04)$. Without desiccation pre-treatment, the percentage volumetric expansion for all materials was higher at $1 \mathrm{~m}$ compared to $1 \mathrm{w}$ and the difference was significant for $\mathrm{BD}(p=0.002)$. With desiccation, 10 showed lower expansion at $1 \mathrm{~m}$ compared to $1 \mathrm{w}$ but the difference was not significant $(p=0.74)$. 
Volumetric expansion for FJ was negative at both $1 \mathrm{w}$ and $1 \mathrm{~m}$ when desiccated, however, the value was significantly higher at $1 \mathrm{~m}$ compared to $1 \mathrm{w}(p=0.02)$.

Volumetric expansion of all materials was positively correlated to sorption (Pearson correlation coefficient $=0.67$ ) and negatively correlated to solubility (Pearson correlation coefficient $=-0.67)$ when no desiccation pre-storage treatment was applied $(p<0.005)$. 


\section{Discussion}

Several materials are being used as dentine replacement materials such as glass ionomers, resin modified glass ionomers, bulk-fill resin-composites, and more recently, water-based calcium silicate materials such as BD have been introduced. Although these materials are not directly exposed to the oral environment, they may be indirectly affected by oral fluids through microleakage, defective restoration margins or delaying final restoration placement. Furthermore, some materials like BD should be left uncovered with a final resincomposite restoration for at least two weeks since the polymerisation contraction force of composite may disturb BD during its early stages of setting [22]. This leaves the material in direct exposure to the oral fluids for a significant length of time before the final restoration is placed.

The current study assessed water sorption, solubility, and hygroscopic expansion for a number of dentine replacement materials including FJ (a conventional glass ionomer), 10 (a resin-modified glass ionomer) and BD (a calcium-silicate based material). The values of sorption, solubility, and volumetric expansion were significantly different between different materials (with the exception of volumetric expansion of non-desiccated FJ and BD), thus, the first null hypothesis was rejected. Furthermore, there was significant effect of preimmersion dryness (desiccation) on water sorption, solubility, and volumetric expansion values. As a result, the second hypothesis was also rejected.

Based on the results of the present study, solubility values were in the following order: BD> FJ> $10(7.34 \%, 4.44 \%$ and $1.29 \%$ respectively). BD had the highest solubility compared to tested materials. Its solubility $(7.34 \%)$ was slightly higher than that stated by the manufacturer (6.8\%) [33]. A previous study has even reported a higher solubility value of $11.83 \%$ for BD [33]. This could be related to the hydration reaction products (calcium salts and calcium hydroxide) which are highly soluble with low wash out resistance $[33,34]$. The high solubility of BD is critical for the restoration performance since calcium hydroxide hydrolysis may result in collagen denaturation which might lead to BD crystallization inside dental tubules. This results in forming a tag-like structure which is called the 'mineral infiltration zone' which improve micromechanical bonding [35]. 
The high solubility of BD is also associated with high amounts of $\mathrm{Ca}$ and $\mathrm{Si}$ ion release, which are important in its bioactivity [36]. The high BD solubility has been reported in previous studies compared to other calcium silicate materials [33, 34, 37]. IO showed the lowest solubility in the current study which may be explained by the presence of a more stable polymeric structure in its matrix compared to FJ and BD [38].

In the current study, sorption values with no desiccation pre-storage treatment were in the following order: IO> BD> FJ (6.56\%, 5.79\%, and 5.36\% respectively). The high water sorption of 10 compared to other materials might be attributed to the presence of the highly hydrophilic HEMA or modified HEMA monomer in its composition [39]. The presence of HEMA also increases its solubility compared to resin-composites because of its low molecular weight and high mobility [40]. Furthermore, the incomplete curing and conversion process of this monomer may contribute to the rapid water uptake and degradation of the matrix [23]. This finding is in line with another study that showed that a RMGIC had higher water sorption at equilibrium than Fuji IX after one month [38]. BD, on the other hand, showed low sorption which is consistent with a previous study in which BD showed water sorption comparable to IRM [32]. This can be attributed to the water reducing agent (superplasticizer) and the rapid hydration reaction in BD [33].

BD showed negative percentage mass change values, which increased in negative value with time, while IO and FJ showed positive values. There was sharp mass loss of BD directly after water immersion $(1 \mathrm{~h})$ then it steadily increased in negative value by the end of the immersion period (30 days). This may be attributed to the high BD solubility with low water uptake to overcome the ions loss which means that material solubility was higher than water uptake [32]. In the oral environment, BD solubility might be reduced by the calcium phosphate deposits which are formed on the surface [32]. These depositions were reported for tri- calcium silicate materials and Portland cement $[41,42]$. This observation was also supported by lower BD solubility in buffered solution [37]. Moreover, the exposed surface of the material in a clinical situation may be less than that in a laboratory setting, thus reducing the material's solubility.

The results showed low percentage mass change for 10 compared to FJ at $1 \mathrm{~h}$ and $24 \mathrm{~h}$ followed by higher mass change of IO compared to FJ thereafter. This might be explained by 
the complete hardening of FJ [28]. The initial increase of mass of FJ compared to IO may have resulted from its rapid maturation reaction within the first $24 \mathrm{~h}$. This is in line with a previous study that reported that FJ had lower initial solubility at $24 \mathrm{~h}$ and $7 \mathrm{~d}$ compared to other GIC materials assessed using the evaporation method $[27,43]$. It should be noted, however, that the percentage mass change does not necessarily relate to solubility. One of the limitations of measuring weight difference is that it does not accurately represent material solubility. It also records the disintegration processes such as loss of materials particles in water during storage [37]. Therefore, the end result is a combination of these two processes and there is no clear differentiation between them.

The effect of desiccation on the properties and maturation of water-based restorative materials has been previously assessed. However, the current study is the first one to assess the effect of desiccation on water sorption, solubility, and hygroscopic expansion of waterbased materials including BD. According to this study, the pre-storage treatment had a significant effect on sorption, solubility, and hygroscopic expansion in all tested materials. It was highlighted in a previous study that desiccation of glass ionomer in order to measure the initial dry mass may result in structural modifications that affect glass ionomer sorption and solubility [44]. Desiccation may result in loss of free unbound water of materials during their maturation which could extend in the case of glass ionomer from $24 \mathrm{~h}$ to $72 \mathrm{~h}$ [45]. Crazing and stopping of maturation reaction that occur when the material is desiccated at early setting stages result in major changes in physical properties of glass ionomer $[38,46]$. It was not applicable to assess the effect of desiccation on sorption and solubility of BD in the current study since all samples were fractured within the first hour of water immersion following $B D$ desiccation. This might be attributed to the fact that $B D$ is a water-based material in which water plays an important role in the material composition and setting reaction.

The current study showed that both FJ and IO were affected significantly by desiccation, however, the effect of desiccation on sorption and solubility of FJ was significantly much higher than on 10 which is in agreement with a previous study [47]. This can be explained by the polymeric content of 10 which offset the moisture sensitivity of the glass ionomer component [48]. However, it did not totally eliminate the dehydration effect on resin 
modified glass ionomer [47]. Furthermore, it is generally accepted that GIC is a water-based material and water plays an important role in its setting reaction [49].

Interestingly, the effect of desiccation on the percentage mass change of FJ was much more significant than the effect of wet treatment. This observation was also reported in other studies $[50,51]$. The effect of early desiccation on contraction of the material has been shown to be much higher than expansion effect associated with early hydration in GIC [51].

In the current study, volumetric expansion was assessed using a laser micrometre. The main advantage of this method over the traditionally used Archimedes method is its higher accuracy since measurements are not affected by the solubility which could affect the density of the storage medium and result in false negative values [52]. All materials showed positive volumetric expansion with water immersion when no pre-storage desiccation treatment was applied. Volumetric expansion is mainly explained by the continued water uptake during storage which is confirmed by the positive correlation with sorption values. 10 demonstrated the highest volumetric expansion (6.19\%) which could be mainly attributed to its hydrophilic HEMA monomer content combined with a weekly cross-linked polymer network. A similar volumetric expansion value for a RMGIC has been previously reported (7.97\%) when the material was immersed in water for 30 days [52]. The amount of volumetric expansion of 10 and FJ was significantly lower when the materials were desiccated prior to water immersion which is attributed to structural changes induced by dehydration. This is in line with the sorption values that were similarly decreased with desiccation.

An interesting finding in the current study is that desiccated FJ has exhibited negative hygroscopic expansion (or shrinkage) when immersed in water despite its positive sorption and negative solubility. This can be explained by the 'self-healing' effect described earlier by Sidhu et al. (1997) which entails that the internal cracks that develop in a glass ionomer material when dehydrated are reparable upon rehydration [47]. Accordingly, the shrinkage of desiccated FJ could be due to the healing effect of water which reduces the internal cracks and binds the material together reducing its volume. Self-healing might not be applicable to BD since the desiccated samples were cracked and broken once they were 
immersed in water. Thus, it is imperative to avoid excessive or prolonged dryness of a BD restoration during rubber dam isolation and finishing procedures.

\section{Conclusions}

- BD had the highest solubility after one-month water immersion and its volumetric expansion is similar to FJ.

- IO had the highest sorption and volumetric expansion and the lowest solubility after one month of immersion in water which could be attributed to its polymeric resin content.

- Desiccation before water immersion had significant effect on sorption, solubility, and volumetric expansion of the assessed materials especially FJ and BD. Accordingly, the ISO (4049) standard for assessing water sorption and solubility of polymeric materials is not applicable for water-based materials. 


\section{References}

[1] Camilleri J. Investigation of Biodentine as dentine replacement material. Journal of Dentistry. 2013;41:600-10.

[2] Yap AU. Resin-modified glass ionomer cements: a comparison of water sorption characteristics. Biomaterials. 1996;17:1897-900.

[3] Zainuddin N, Karpukhina N, Hill RG, Law RV. A long-term study on the setting reaction of glass ionomer cements by 27 Al MAS-NMR spectroscopy. Dental Materials. 2009;25:290-5.

[4] Ngo HC, Mount G, Mc Intyre J, Tuisuva J, Von Doussa R. Chemical exchange between glass-ionomer restorations and residual carious dentine in permanent molars: an in vivo study. Journal of Dentistry. 2006;34:608-13.

[5] Koubi S, Raskin A, Dejou J, About I, Tassery H, Camps J, Proust J. Effect of dual cure composite as dentin substitute on the marginal integrity of Class II open-sandwich restorations. Operative Dentistry. 2010;35:165-71.

[6] Nagaraja Upadhya P, Kishore G. Glass ionomer cement: the different generations. Trends in Biomaterials \& Artificial Organs. 2005;18:158-65.

[7] Khoroushi M, Keshani F. A review of glass-ionomers: From conventional glass-ionomer to bioactive glass-ionomer. Dental Research Journal. 2013;10:411-20.

[8] Guggenberger R, May R, Stefan K. New trends in glass-ionomer chemistry. Biomaterials. 1998;19:479-83.

[9] Gjorgievska ES, Nicholson JW, Apostolska SM, Coleman NJ, Booth SE, Slipper IJ, Mladenov MI. Interfacial properties of three different bioactive dentine substitutes. Microscopy and Microanalysis. 2013;19:1450-7.

[10] Arslan S, Demirbuga S, Ustun Y, Dincer AN, Canakci BC, Zorba YO. The effect of a newgeneration flowable composite resin on microleakage in Class $V$ composite restorations as an intermediate layer. Journal of Conservative Dentistry. 2013;16:189.

[11] Bachoo I, Seymour D, Brunton P. A biocompatible and bioactive replacement for dentine: is this a reality? The properties and uses of a novel calcium-based cement. British Dental Journal. 2013;214:E5-E.

[12] Attik G, Villat C, Hallay F, Pradelle-Plasse N, Bonnet H, Moreau K, Colon P, Grosgogeat B. In vitro biocompatibility of a dentine substitute cement on human MG63 osteoblasts cells: Biodentine $^{\mathrm{TM}}$ versus MTA ${ }^{\circledR}$. International Endodontic Journal. 2014;47:1133-41. 
[13] Camilleri J, Sorrentino F, Damidot D. Investigation of the hydration and bioactivity of radiopacified tricalcium silicate cement, Biodentine and MTA Angelus. Dental Materials. 2013;29:580-93.

[14] Grech L, Mallia B, Camilleri J. Characterization of set Intermediate Restorative Material, Biodentine, Bioaggregate and a prototype calcium silicate cement for use as root-end filling materials. International Endodontic Journal. 2013;46:632-41.

[15] Villat C, Tran V, Pradelle-Plasse N, Ponthiaux P, Wenger F, Grosgogeat B, Colon P. Impedance methodology: a new way to characterize the setting reaction of dental cements. Dental Materials. 2010;26:1127-32.

[16] Laurent P, Camps J, About I. BiodentineTM induces TGF- $\beta 1$ release from human pulp cells and early dental pulp mineralization. International Endodontic Journal. 2012;45:439-48. [17] Poggio C, Arciola CR, Beltrami R, Monaco A, Dagna A, Lombardini M, Visai L. Cytocompatibility and antibacterial properties of capping materials. The Scientific World Journal. 2014;2014.

[18] Khedmat S, Dehghan S, Hadjati J, Masoumi F, Nekoofar MH, Dummer PMH. In vitro cytotoxicity of four calcium silicate-based endodontic cements on human monocytes, a colorimetric MTT assay. Restorative Dentistry \& Endodontics. 2014;39:149-54.

[19] Opdam NJM, van de Sande FH, Bronkhorst E, Cenci MS, Bottenberg P, Pallesen U, Gaengler P, Lindberg A, Huysmans MCDNJM, van Dijken JWV. Longevity of posterior composite restorations: a systematic review and meta-analysis. J Dent Res. 2014; 93:943949.

[20] Zayed, M.M., Hassan, R.E. and Riad, M.I. Evaluation of the antibacterial efficacy of different bioactive lining and pulp capping agents. Tanta Dental Journal. 2015; 12:132-139. [21] Koubi S, Elmerini H, Koubi G, Tassery H, Camps J. Quantitative evaluation by glucose diffusion of microleakage in aged calcium silicate-based open-sandwich restorations. International Journal of Dentistry. 2011;2012.

[22] Hashem DF, Foxton R, Manoharan A, Watson TF, Banerjee A. The physical characteristics of resin composite-calcium silicate interface as part of a layered/laminate adhesive restoration. Dental Materials. 2014;30:343-9.

[23] Fano L, Fano V, Ma W, Wang X, Zhu F. Hydrolytic degradation and cracks in resin-modified glass-ionomer cements. Journal of Biomedical Materials Research Part B: Applied Biomaterials. 2004;69:87-93. 
[24] McCabe JF, Walls AW. Applied dental materials 9th edition: John Wiley \& Sons; 2013.

[25] Saghiri MA, Asgar K, Lotfi M, Karamifar K, Neelakantan P, Ricci JL. Application of mercury intrusion porosimetry for studying the porosity of mineral trioxide aggregate at two different pH. Acta Odontologica Scandinavica. 2012;70:78-82.

[26] Gomes DJ, Costa MHdN, Sousa ERd, Lund RG. Coronal microleakage of endodontically treated teeth with intracanal post exposed to fresh human saliva. Journal of Applied Oral Science. 2013;21:403-8.

[27] Peez R, Frank S. The physical-mechanical performance of the new $\mathrm{Ketac}^{\mathrm{TM}}$ Molar Easymix compared to commercially available glass ionomer restoratives. Journal of Dentistry. 2006;34:582-7.

[28] Aliping-McKenzie M, Linden R, Nicholson J. The effect of saliva on surface hardness and water sorption of glass-ionomers and "compomers". Journal of Materials Science: Materials in Medicine. 2003;14:869-73.

[29] Moshaverinia A, Ansari S, Roohpour N, Reshad M, Schricker SR, Chee WW. Effects of Nvinylcaprolactam containing polyelectrolytes on hardness, fluoride release and water sorption of conventional glass ionomers. The Journal of Prosthetic Dentistry. 2011;105:32331.

[30] Ferracane JL, Hilton TJ, Stansbury JW, Watts DC, Silikas N, Ilie N, et al.,. Academy of Dental Materials guidance-Resin composites: Part II-Technique sensitivity (handling, polymerization, dimensional changes). Dent Mater. 2017;33:1171-1191

[31] Wei Y-j, Silikas N, Zhang Z-t, Watts DC. Hygroscopic dimensional changes of selfadhering and new resin-matrix composites during water sorption/desorption cycles. Dental Materials. 2011;27:259-66.

[32] Grech L, Mallia B, Camilleri J. Investigation of the physical properties of tricalcium silicate cement-based root-end filling materials. Dental Materials. 2013;29:e20-e8.

[33] Gandolfi MG, Siboni F, Botero T, Bossù M, Riccitiello F, Prati C. Calcium silicate and calcium hydroxide materials for pulp capping: biointeractivity, porosity, solubility and bioactivity of current formulations. Journal of Applied Biomaterials \& Functional Materials. 2014.

[34] Gandolfi MG, Siboni F, Polimeni A, Bossù M, Riccitiello F, Rengo S, Prati C. In vitro screening of the apatite-forming ability, biointeractivity and physical properties of a 
tricalcium silicate material for endodontics and restorative dentistry. Dentistry Journal. 2013;1:41-60.

[35] Abu Zeid STH, Alothmani OS, Yousef MK. Biodentine and Mineral Trioxide Aggregate: An Analysis of Solubility, $\mathrm{pH}$ Changes and Leaching Elements. Life Science Journal. $2015 ; 12: 18-23$.

[36] Han L, Okiji T. Bioactivity evaluation of three calcium silicate-based endodontic materials. International Endodontic Journal. 2013;46:808-14.

[37] Kaup M, Schäfer E, Dammaschke T. An in vitro study of different material properties of Biodentine compared to ProRoot MTA. Head \& Face Medicine. 2015;11:1.

[38] Cefaly DFG, Franco EB, Mondelli RFL, Francisconi PAS, Navarro MFdL. Diametral tensile strength and water sorption of glass-ionomer cements used in Atraumatic Restorative Treatment. Journal of Applied Oral Science. 2003;11:96-101.

[39] Cattani-Lorente M, Dupuis V, Moya F, Payan J, Meyer J-M. Comparative study of the physical properties of a polyacid-modified composite resin and a resin-modified glass ionomer cement. Dental Materials. 1999;15:21-32.

[40] Dhanpal P, Yiu C, King N, Tay F, Hiraishi N. Effect of temperature on water sorption and solubility of dental adhesive resins. Journal of Dentistry. 2009;37:122-32.

[41] Tay FR, Pashley DH, Rueggeberg FA, Loushine RJ, Weller RN. Calcium phosphate phase transformation produced by the interaction of the Portland cement component of white mineral trioxide aggregate with a phosphate-containing fluid. Journal of Endodontics. 2007;33:1347-51.

[42] Camilleri J. Characterization and hydration kinetics of tricalcium silicate cement for use as a dental biomaterial. Dental Materials. 2011;27:836-44.

[43] Tapsir Z, Ahmed HMA, Luddin N, Husein A. Sealing ability of various restorative materials as coronal barriers between endodontic appointments. The Journal of Contemporary Dental Practice. 2013;14:47-50.

[44] Pieper C, Zanchi C, Rodrigues-Junior S, Moraes R, Pontes L, Bueno M. Sealing ability, water sorption, solubility and toothbrushing abrasion resistance of temporary filling materials. International Endodontic Journal. 2009;42:893-9.

[45] Pearson G, Atkinson A. Long-term flexural strength, of glass ionomer cements. Biomaterials. 1991;12:658-60. 
[46] McLean J. Clinical applications of glass-ionomer cements. Operative Dentistry. 1991:184-90.

[47] Sidhu S, Sherriff M, Watson T. The effects of maturity and dehydration shrinkage on resin-modified glass-ionomer restorations. Journal of Dental Research. 1997;76:1495-501.

[48] Fatima N, Ali AS, Qazi F, Jat SA. Effectiveness of commonly available surface protecting agents in maintaining microhardness of two cements. Journal of the College of Physicians and Surgeons--Pakistan: JCPSP. 2013;23:315-8.

[49] Barry TI, Clinton DJ, Wilson AD. The Structure of a Glass-lo nomer Cement and its Relationship to the Setting Process. Journal of Dental Research. 1979;58:1072-9.

[50] Sidhu SK, Pilecki P, Sherriff M, Watson TF. Crack closure on rehydration of glass-ionomer materials. European Journal of Oral Sciences. 2004;112:465-9.

[51] Wilson A, Paddon J. Dimensional changes occurring in a glass-ionomer cement. American Journal of Dentistry. 1993;6:280-2.

[52] Watts D, Kisumbi B, Toworfe G. Dimensional changes of resin/ionomer restoratives in aqueous and neutral media. Dental Materials. 2000;16:89-96. 


\section{Table legends}

Table 1 Test materials and manufacturer information.

Table 2 Sorption and solubility data of different materials with two types of pre-storage treatment (with desiccation or without desiccation). Data represent the mean values and standard deviation. Different superscript letters per column (upper case for 'with desiccation' or lower case for 'without desiccation') represent values with significant difference according to independent samples T-test and Tukey HSD post hoc test $(\alpha=0.05)$. NA stands for not applicable.

Table 3 Percentage mass change (PMC) data for different materials with two types of different pre-storage treatment (with desiccation or without desiccation). Data represent the mean values and standard deviation. Different superscript letters per column (upper case for 'with desiccation' or lower case for 'without desiccation') represent values with significant difference according to independent samples T-test and Dunnett T3 post hoc test $(\alpha=0.05) .1 \mathrm{~h}, 1 \mathrm{~d}, 3 \mathrm{~d}, 1 \mathrm{w}, 1$ and $1 \mathrm{~m}$ stand for: 1 hour, 1 day, 3 days, 1 week, and 1 month respectively. NA stands for not applicable.

Table 4 Percentage volumetric expansion for different materials with two types of prestorage treatment (with desiccation or without desiccation). Data represent the mean values and standard deviation. Different superscript letters per column (upper case for ' with desiccation' or lower case for 'without desiccation') represent values with significant difference according to independent samples T-test and Tukey HSD post hoc test $(\alpha=0.05)$. $1 \mathrm{w}$ and $1 \mathrm{~m}$ stand for: 1 week and 1 month respectively. NA stands for not applicable. 


\section{Figure legends}

Figure 1 Line chart representing percentage mass change over time (one month) for the different materials with two different types of pre-storage treatment (without desiccation: dashed line, with desiccation: solid line). Note the negative values for BD. Error bars represent standard deviation.

Figure 2 Line chart representing percentage mass change over one week for the different materials with two different types of pre-storage treatment (without desiccation: dashed line, with desiccation: solid line). Note the negative values for BD. Error bars represent standard deviation. 
Table 1 Test materials and manufacturer information.

\begin{tabular}{|l|l|l|l|l|}
\hline \multicolumn{1}{|c|}{ Materials } & $\begin{array}{l}\text { Code } \\
\text { name }\end{array}$ & \multicolumn{1}{|c|}{$\begin{array}{c}\text { Type of } \\
\text { Material }\end{array}$} & \multicolumn{1}{|c|}{ Composition } & \multicolumn{1}{c|}{ Manufacturer } \\
\hline Biodentine & BD & $\begin{array}{l}\text { Calcium } \\
\text { silicate-based } \\
\text { material } \\
\text { (Capsule) }\end{array}$ & $\begin{array}{l}\text { Powder (0.7g): tricalcium } \\
\text { silicate, dicalcium silicate, } \\
\text { calcium carbonate and oxide } \\
\text { filler, iron oxide shade, } \\
\text { zirconium oxide } \\
\text { Liquid (5 drops of water): } \\
\text { Water, calcium chloride, water } \\
\text { reducing agent }\end{array}$ & $\begin{array}{l}\text { Septodont, St } \\
\text { Maure des } \\
\text { Fossés, France }\end{array}$ \\
\hline $\begin{array}{l}\text { GC Fuji IX GP } \\
\text { FAST }\end{array}$ & FJ & $\begin{array}{l}\text { Conventional } \\
\text { glass } \\
\text { ionomer } \\
\text { (Capsule) }\end{array}$ & $\begin{array}{l}\text { Powder: alumino-fluoro-silicate } \\
\text { glassand polyacrylic acid } \\
\text { powder. } \\
\text { Liquid: distilled water, } \\
\text { polyacrylic acid, polybasic } \\
\text { carboxylic acid. }\end{array}$ & $\begin{array}{l}\text { GC } \\
\text { Inc. }\end{array}$ \\
\hline lonolux & IO & $\begin{array}{l}\text { Resin } \\
\text { modified } \\
\text { glass } \\
\text { ionomer } \\
\text { mix) }\end{array}$ & $\begin{array}{l}\text { Powder(12g): Aluminosilicate } \\
\text { glass, pigments, amine. }\end{array}$ & $\begin{array}{l}\text { Voco, } \\
\text { Cuxhaven, } \\
\text { Liquid(5ml): Poly acrylic acids, } \\
\text { distilled water, HEMA, Glycerine } \\
\text { dimethacrylate, Urethane } \\
\text { dimethacrylate monomer, } \\
\text { Butylhydroxytoluol, } \\
\text { camphoroquinone }\end{array}$ \\
\hline
\end{tabular}


Table 2 Sorption and solubility data of different materials with two types of pre-storage treatment (with desiccation or without desiccation). Data represent the mean values and standard deviation. Different superscript letters per column (upper case for 'with desiccation' or lower case for 'without desiccation') represent values with significant difference according to independent samples T-test and Tukey HSD post hoc test $(\alpha=0.05)$. NA stands for not applicable.

\begin{tabular}{|c|l|r|r|r|r|}
\hline \multirow{2}{*}{ Material } & \multicolumn{1}{|c|}{ Storage } & $\begin{array}{c}\text { Sorption } \\
\left(\mu \mathrm{g} / \mathrm{mm}^{3}\right)\end{array}$ & $\begin{array}{c}\text { Solubility } \\
\left(\mu \mathrm{g} / \mathrm{mm}^{3}\right)\end{array}$ & $\begin{array}{c}\text { Sorption } \\
(\%)\end{array}$ & \multicolumn{1}{c|}{$\begin{array}{c}\text { Solubility } \\
(\%)\end{array}$} \\
\hline \multirow{2}{*}{ IO } & $\begin{array}{l}\text { With } \\
\text { desiccation }\end{array}$ & $124.33(0.29)^{\mathrm{a}}$ & $-12.36(0.23)^{\mathrm{a}}$ & $6.43(0.10)^{\mathrm{a}}$ & $-0.64(0.01)^{\mathrm{a}}$ \\
\cline { 2 - 7 } & $\begin{array}{l}\text { Without } \\
\text { desiccation }\end{array}$ & $130.35(0.68)^{\mathrm{A}}$ & $25.67(0.54)^{\mathrm{A}}$ & $6.56(0.05)^{\mathrm{A}}$ & $1.29(0.03)^{\mathrm{A}}$ \\
\hline \multirow{2}{*}{ FJ } & $\begin{array}{l}\text { With } \\
\text { desiccation }\end{array}$ & $79.97(0.76)^{\mathrm{b}}$ & $-20.19(0.35)^{\mathrm{b}}$ & $3.84(0.08)^{\mathrm{b}}$ & $-0.97(0.03)^{\mathrm{b}}$ \\
\cline { 2 - 7 } & $\begin{array}{l}\text { Without } \\
\text { desiccation }\end{array}$ & $107.70(0.33)^{\mathrm{B}}$ & $88.82(1.28)^{\mathrm{B}}$ & $5.36(0.12)^{\mathrm{B}}$ & $4.44(0.16)^{\mathrm{B}}$ \\
\hline \multirow{2}{*}{ BD } & $\begin{array}{l}\text { With } \\
\text { desiccation }\end{array}$ & $\mathrm{NA}$ & $\mathrm{NA}$ & $\mathrm{NA}$ & $\mathrm{NA}$ \\
\cline { 2 - 7 } & $\begin{array}{l}\text { Without } \\
\text { desiccation }\end{array}$ & $122.07(1.09)^{\mathrm{C}}$ & $154.83(1.88)^{\mathrm{C}}$ & $5.79(0.08)^{\mathrm{C}}$ & $7.34(0.09)^{\mathrm{C}}$ \\
\hline
\end{tabular}


Table 3 Percentage mass change (PMC) data for different materials with two types of different pre-storage treatment (with desiccation or without desiccation). Data represent the mean values and standard deviation. Different superscript letters per column (upper case for 'with desiccation' or lower case for 'without desiccation') represent values with significant difference according to independent samples T-test and Dunnett T3 post hoc test $(\alpha=0.05)$. $1 \mathrm{~h}, 1 \mathrm{~d}, 3 \mathrm{~d}, 1 \mathrm{w}, 1$ and $1 \mathrm{~m}$ stand for: 1 hour, 1 day, 3 days, 1 week, and 1 month respectively. NA stands for not applicable.

\begin{tabular}{|c|c|c|c|c|c|c|}
\hline Material & Storage & $\begin{array}{c}\text { PMC (1 h) } \\
(\%)\end{array}$ & $\begin{array}{c}\text { PMC (1 d) } \\
(\%)\end{array}$ & $\begin{array}{c}\text { PMC (3 d) } \\
(\%)\end{array}$ & $\begin{array}{c}\text { PMC (1 w) } \\
(\%)\end{array}$ & $\begin{array}{c}\text { PMC (1 m) } \\
(\%)\end{array}$ \\
\hline \multirow{2}{*}{10} & $\begin{array}{l}\text { With } \\
\text { desiccation }\end{array}$ & $\begin{array}{c}0.51 \\
(0.07)^{\mathrm{a}}\end{array}$ & $\begin{array}{c}2.47 \\
(0.13)^{\mathrm{a}}\end{array}$ & $\begin{array}{c}4.87 \\
(0.27)^{\mathrm{a}}\end{array}$ & $\begin{array}{c}6.58 \\
(0.29)^{\mathrm{a}}\end{array}$ & $\begin{array}{c}7.07 \\
(0.10)^{\mathrm{a}}\end{array}$ \\
\hline & $\begin{array}{l}\text { Without } \\
\text { desiccation }\end{array}$ & $\begin{array}{c}0.51 \\
(0.06)^{A}\end{array}$ & $\begin{array}{c}2.27 \\
(0.33)^{A}\end{array}$ & $\begin{array}{c}3.65 \\
(0.69)^{A}\end{array}$ & $\begin{array}{c}4.16 \\
(0.72)^{A}\end{array}$ & $\begin{array}{c}5.27 \\
(0.05)^{A}\end{array}$ \\
\hline \multirow{2}{*}{ FJ } & $\begin{array}{l}\text { With } \\
\text { desiccation }\end{array}$ & $\begin{array}{c}2.58 \\
(0.46)^{b}\end{array}$ & $\begin{array}{c}3.56 \\
(0.20)^{\mathrm{b}}\end{array}$ & $\begin{array}{c}3.87 \\
(0.27)^{\mathrm{b}}\end{array}$ & $\begin{array}{c}4.25 \\
(0.13)^{\mathrm{b}}\end{array}$ & $\begin{array}{c}4.80 \\
(0.11)^{b}\end{array}$ \\
\hline & $\begin{array}{l}\text { Without } \\
\text { desiccation }\end{array}$ & $\begin{array}{c}0.35 \\
(0.03)^{\mathrm{B}}\end{array}$ & $\begin{array}{c}0.52 \\
(0.09)^{\mathrm{B}}\end{array}$ & $\begin{array}{c}0.66 \\
(0.10)^{\mathrm{B}}\end{array}$ & $\begin{array}{c}0.80 \\
(0.14)^{\mathrm{B}}\end{array}$ & $\begin{array}{c}0.92 \\
(0.06)^{B}\end{array}$ \\
\hline \multirow{2}{*}{ BD } & $\begin{array}{l}\text { With } \\
\text { desiccation }\end{array}$ & NA & NA & NA & NA & NA \\
\hline & $\begin{array}{l}\text { Without } \\
\text { desiccation }\end{array}$ & $\begin{array}{c}-0.06 \\
(0.01)^{c}\end{array}$ & $\begin{array}{l}-0.078 \\
(0.14)^{C}\end{array}$ & $\begin{array}{c}-0.80 \\
(0.16)^{C}\end{array}$ & $\begin{array}{c}-0.90 \\
(0.12)^{C}\end{array}$ & $\begin{array}{c}-1.55 \\
(0.13)^{C}\end{array}$ \\
\hline
\end{tabular}


Table 4 Percentage volumetric expansion for different materials with two types of prestorage treatment (with desiccation or without desiccation). Data represent the mean values and standard deviation. Different superscript letters per column (upper case for 'with desiccation' or lower case for 'without desiccation') represent values with significant difference according to independent samples T-test and Tukey HSD post hoc test $(\alpha=0.05) .1$ $\mathrm{w}$ and $1 \mathrm{~m}$ stand for: 1 week and 1 month respectively. NA stands for not ap plicable.

\begin{tabular}{|c|c|c|c|}
\hline Material & Storage & $\begin{array}{c}\text { Volumetric } \\
\text { expansion (1 W) } \\
\%\end{array}$ & $\begin{array}{c}\text { Volumetric expansion } \\
\qquad(1 \mathrm{~m}) \\
\%\end{array}$ \\
\hline \multirow{2}{*}{10} & $\begin{array}{c}\text { With } \\
\text { desiccation }\end{array}$ & $3.31(1.34)^{a}$ & $3.01(1.95)^{a}$ \\
\hline & $\begin{array}{c}\text { Without } \\
\text { desiccation }\end{array}$ & $5.82(1.80)^{\mathrm{A}}$ & $6.19(2.21)^{\mathrm{A}}$ \\
\hline \multirow{2}{*}{ FJ } & $\begin{array}{c}\text { With } \\
\text { desiccation }\end{array}$ & $-2.92(1.36)^{b}$ & $-2.35(1.04)^{b}$ \\
\hline & $\begin{array}{c}\text { Without } \\
\text { desiccation }\end{array}$ & $0.81(0.73)^{B}$ & $1.02(0.59)^{B}$ \\
\hline \multirow{2}{*}{ BD } & $\begin{array}{c}\text { With } \\
\text { desiccation }\end{array}$ & NA & NA \\
\hline & $\begin{array}{c}\text { Without } \\
\text { desiccation }\end{array}$ & $0.96(2.21)^{B}$ & $1.51(2.10)^{B}$ \\
\hline
\end{tabular}




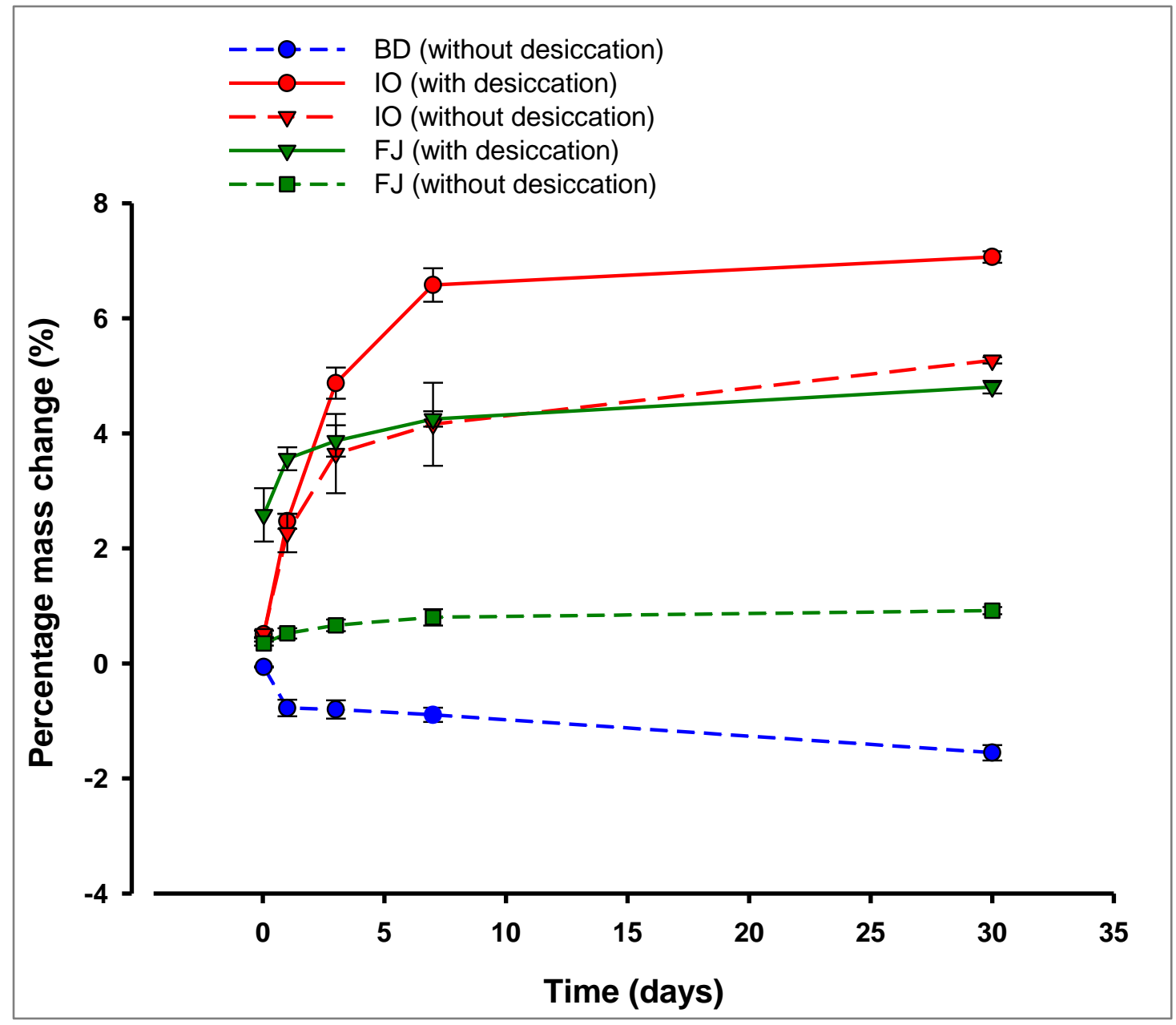

Figure 1 Line chart representing percentage mass change over time (one month) for the different materials with two different types of pre-storage treatment (without desiccation: dashed line, with desiccation: solid line). Note the negative values for BD. Error bars represent standard deviation. 


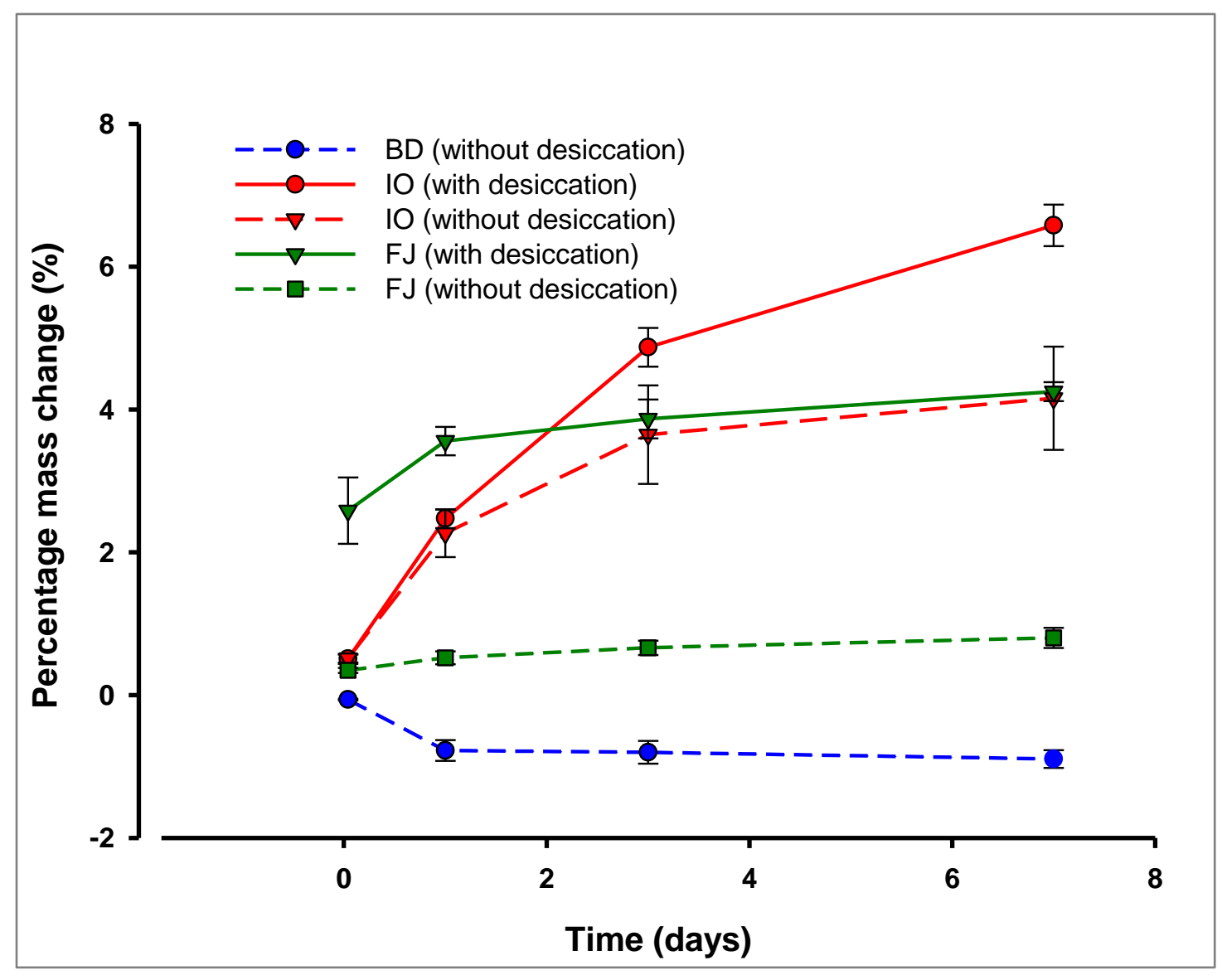

Figure 2 Line chart representing percentage mass change over one week for the different materials with two different types of pre-storage treatment (without desiccation: dashed line, with desiccation: solid line). Note the negative values for BD. Error bars represent standard deviation. 